\title{
Long-term influence of simulated territorial intrusions on dawn and dusk singing in the Winter Wren: spring versus autumn
}

\author{
Nathaline Erne $\cdot$ Valentin Amrhein
}

Received: 9 November 2007 / Accepted: 29 January 2008/Published online: 4 March 2008

(C) Dt. Ornithologen-Gesellschaft e.V. 2008

\begin{abstract}
Males of many songbird species have peaks of singing activity at dawn and dusk. Singing during those twilight periods can function in territory proclamation, and males are suggested to adjust song output to the level of intruder pressure. We used song playback during the breeding season to simulate intrusions into territories of male Winter Wrens (Troglodytes troglodytes) shortly after dawn. We then compared male singing behaviour during the dawn and dusk chorus before and 1 day after the simulated intrusion. One day after the playback, male Wrens increased their song output before sunrise, which confirms our results from a previous study on dawn singing in autumn territories. At dusk, on the evening following the playback, males slightly increased song output after sunset, but singing activity at dusk was generally very low. We found no significant changes of song output after sunrise, before sunset, and between 2 days of control without playback. These results are consistent with the hypothesis that dawn and dusk singing is important for territory defence in spring. Unlike in autumn, however, increased singing in spring at dawn and dusk could also serve to defend other resources such as fertile mates or to strengthen the pair bond after a territorial challenge. In comparison with the results on autumnal singing, male Wrens started singing earlier at dawn during the breeding season, and they
\end{abstract}

Communicated by F. Bairlein.

N. Erne $\cdot$ V. Amrhein

Research Station Petite Camargue Alsacienne,

Rue de la Pisciculture, 68300 Saint-Louis, France

N. Erne $\cdot$ V. Amrhein $(\bowtie)$

Zoological Institute, University of Basel, Vesalgasse 1,

4051 Basel, Switzerland

e-mail:v.amrhein@unibas.ch generally sang more songs at dawn and immediately after playback. The increase in absolute numbers of songs sung in the morning after playback seemed greater in spring than in autumn; however, the proportional increase relative to overall song output was similar in both seasons.

Keywords Dawn chorus - Dusk chorus - Bird song · Song playback · Territory defence

\section{Introduction}

Territorial males of many songbird species show a peak of singing activity at dawn, starting about $60 \mathrm{~min}$ before sunrise (Staicer et al. 1996). A second but smaller peak of song is often found at dusk (McNamara et al. 1987; Staicer et al. 1996). Dawn singing is suggested to function in mate attraction (McNamara et al. 1987; Double and Cockburn 2000), mate guarding (Mace 1987; Welling et al. 1995), and territory defence (Kacelnik and Krebs 1983; McDonald 1989; Slagsvold et al. 1994; Amrhein et al. 2004; Liu 2004; Kunc et al. 2005; Trillo and Vehrencamp 2005).

If dawn singing is important in male-male competition to defend the territory or other limited resources such as fertile females, then males are expected to adjust defence behaviour to preceding territorial challenges and to the level of intruder pressure (Davies and Houston 1984; Stamps and Krishnan 2001). Because such adjustments in behaviour are probably important for long-term tenure of a territory (Switzer et al. 2001), reinforced territory defence is likely to be maintained over some time period after the territorial challenge. It has recently been shown that territorial intrusions simulated by song playback can indeed have effects on the behaviour of males during diurnal singing interactions several hours or days after the 
intrusion (Hall et al. 2006; Schmidt et al. 2007). Furthermore, in a study on autumnal dawn singing of Winter Wrens (Troglodytes troglodytes), males increased song output before sunrise on the day after a simulated territorial intrusion; in contrast, song output after sunrise remained constant or even decreased (Amrhein and Erne 2006).

However, unlike singing in autumn, singing during the breeding season is likely to serve not only to defend a territory but also to attract a mate or to repel other males in order to guard fertile mates (Tobias and Seddon 2000). The way males react to territorial challenges may thus differ between the autumn and breeding seasons (Hyman 2005).

Here, we studied the effect of season on long-term changes in singing behaviour following a simulated territorial intrusion. As in the previous autumn study (Amrhein and Erne 2006), we made an interactive song playback in spring $1 \mathrm{~h}$ after sunrise and compared the subjects' song output immediately before and 1 day after the playback. If the functions of singing do not vary with time of day, we predicted the Wrens to time a possible long-term reaction to the hour of the intrusion and thus to increase song output in the hour after sunrise. However, if singing before sunrise is particularly important to defend the territory or fertile mates, we predicted a long-term increase in song output before sunrise but not after sunrise, as shown previously in autumnal singing. Furthermore, if repelling rival males is more important during the breeding season, we predicted that a short-term increase of singing directly after the playback and a long-term increase in dawn singing are more pronounced in spring than in autumn. We thus compared the effects of a simulated territorial intrusion on song output in spring with the results obtained in autumn (Amrhein and Erne 2006). Additionally, we surveyed song output at dawn on the day before playback, to study natural variation in undisturbed dawn singing activity as a control. Because singing after sunset was suggested to have similar functions as singing at dawn (Cuthill and Macdonald 1990; Staicer et al. 1996), we also studied the influence of the territorial intrusions simulated in the morning on song output at dusk.

\section{Methods}

\section{General}

We conducted the study at the Petite Camargue Alsacienne in the Upper Rhine Valley in France, $10 \mathrm{~km}$ north of Basel, Switzerland. The area comprises a $1-\mathrm{km}^{2}$ mosaic of riverine forests, scrubs, pastures, fields, reeds and artificial lakes. The study was conducted from 24 March to 3 June 2005 and, during that time, there were 22-24 territorial Wrens present at the study site. The Wrens were unbanded, and we did not survey the mating status of our subjects. We distinguished between individuals on the basis of their well-separated song posts and territories. We checked our subjects' territories about every other day, to verify that they were occupied throughout the field season.

\section{Study species}

Resident male Wrens defend territories and sing throughout the year (Armstrong 1955; Glutz von Blotzheim 1985; Cramp 1988). Females neither defend territories nor sing territorial song (Armstrong 1955; Dallmann 1987). Wrens form pair bonds during spring courtship and mating only (Armstrong 1955; Dallmann 1987; Cramp 1988), and outside the breeding season resident males are generally solitary (Cramp 1988). During the breeding season, male Wrens usually start building nests about mid-March (Armstrong 1955). Males are often polygynous, but may participate in feeding the young depending on the degree of polygyny (Cramp 1988). Egg laying starts around the middle of April, and the young usually hatch in May. In cases in which a second brood is performed, females start to lay the second clutch in the beginning of June (Glutz von Blotzheim 1985).

\section{Equipment and song recording}

The technical procedures of song recording and playback were the same as in the previous study on autumnal singing behaviour (Amrhein and Erne 2006). To create the playback tapes, the songs of 12 male Wrens were recorded at the study site at dawn from 24 March to 6 April 2005 from less than $10 \mathrm{~m}$ distance with a Sennheiser ME66/K6 directional microphone (Sennheiser Electronic, Germany) and a Sony WM-D6C tape recorder (Sony, Japan). Songs were digitized at $44,100 \mathrm{~Hz}$ and 32 bits using Audacity 1.2.2 for Macintosh. From each recorded male, we selected ten songs at random that were normalized to the peak amplitude. Four repetitions of this series of ten songs were recorded on the playback tapes. Between two songs, we inserted about $400 \mathrm{~ms}$ of silence to allow pressing the pause button during playback to release the songs one by one. Each subject received a playback with songs recorded from a different male of our study population that was not within the subject's hearing range. During the playback, songs were broadcast from a Sony WM-D6C tape recorder through a Blaupunkt GTA 250 amplifier (Blaupunkt, Germany) connected by a $25 \mathrm{~m}$ cable to a Canton Plus X loudspeaker (Canton Elektronik, Germany) placed at a height of about $1.5 \mathrm{~m}$ within the subject's singing territory. While broadcasting the playback, we stood about $20 \mathrm{~m}$ away from the loudspeaker. 
Playback experiment

Playback experiments were performed between 16 April and 3 June. The initial sample size was $n=12$ males. Similar to our previous study (Amrhein and Erne 2006), there was a second singing male Wren present in 1 of the 12 territories during part of the experiment, so data from this trial were not included in the following analyses, and the final sample size was $n=11$ males. For the playback experiments, we chose different territories than we used for the previous study in the preceding autumn.

Each trial with a subject ran for a period of 4 days so that we censused singing activity on three consecutive evenings and mornings, respectively (Fig. 1). Each subject was observed for a total of $13 \mathrm{~h}$, and the 11 subjects were observed for a total of $143 \mathrm{~h}$. The observation periods of 4 days duration for the individual subjects were distributed throughout the time of fieldwork; they did not overlap between subjects and were chosen independently of weather conditions. During the observation and playback sessions, we noted the numbers of songs sung per minute. Before playbacks started with a particular subject on the third observation day, we studied variation in natural singing activity between 2 days without playback as a control. On the third day of each trial, starting $1 \mathrm{~h}$ after sunrise, we made a playback of 3 min duration within the subject's territory, following the same playback protocol as in the previous autumn study (Amrhein and Erne 2006). By pressing the pause button after a song, we released the songs one by one from the playback tape. At the beginning of each trial, we played songs simulating an intruder singing at a natural rate of about 5-6 songs/min (Dallmann 1987). Once and if the subject started singing, we switched to an interactive playback mode by overlapping $41 \pm 18 \%$ (mean $\pm \mathrm{SD}$ ) of the subject's songs, which is likely to simulate a moderately aggressive intruder (Naguib et al.

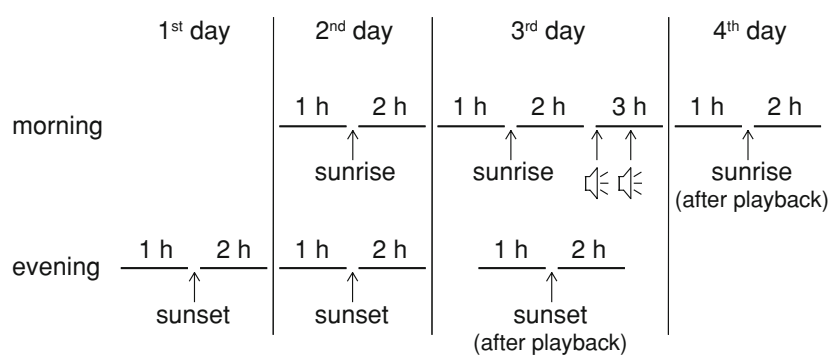

Fig. 1 The setup of the experiment in spring. Each territorial male Winter Wren (Troglodytes troglodytes) was observed during 4 consecutive days, so that dusk and dawn singing could be compared between 2 days of control before playbacks were done on the third day (starting $1 \mathrm{~h}$ after sunrise). Song output after playback was then surveyed in the third dusk and dawn, respectively. The horizontal lines indicate observation durations; the loudspeakers indicate two playbacks of song
2004). After the playback, we rewound the playback tape, and $30 \mathrm{~min}$ after the end of the first playback we repeated the playback with the same order of songs, to simulate a fairly persistent intruder. Each subject thus received a total of 6 min of playback and, in total, $36.5 \pm 4.5$ playback songs (about 6 songs/min). During playback, songs were played at a peak amplitude of $90 \mathrm{~dB}$ (corresponding to the natural sound level of a singing Wren; Armstrong 1977), as measured at $1 \mathrm{~m}$ prior to playbacks using a Brüel \& Kjær precision SPL meter 2233 (C-weighting, fast response; Brüel \& Kjær, Denmark). One subject did not vocally respond to both playbacks, but was seen next to the loudspeaker during both playbacks. Another subject responded vocally only to the first playback. The 11 subjects sang on average $23.4 \pm 10.2$ songs during the 6 min of playback. Following the playback, the subjects were then observed during the evening after the playback and in the next morning, so that, in total, we could compare singing activity between two observation periods without playback and between observation periods before and after a playback (Fig. 1).

\section{Data analysis}

Data analysis was done using R 2.4.1 (R Development Core Team 2006). Unless otherwise noted, values are reported as mean $\pm \mathrm{SD}$, and tests are two-tailed. Linear mixed effects models (lme) were used with individual subject as a random factor, and time of the year (spring or autumn) and census period (before versus after playback) as fixed factors. Non-significant interaction terms were removed from the models, and the assumptions of the linear models were visually checked by plotting standardized residuals against fitted values. The minute of sunrise (given at http://www.sunrisesunset.com for Basel, Switzerland) was defined a priori as a cut-off point in the analyses, as the dawn chorus of birds is usually defined as taking place before sunrise (Staicer et al. 1996; Amrhein and Erne 2006). Similarly, the minute of sunset was defined as a cut-off point for the dusk chorus.

\section{Results}

\section{Observation date}

For the first observations of each trial, before playback, we found no significant influence of observation date during the spring season on start of singing before sunrise (Pearson correlation, $r_{9}=0.55, P=0.082$ ), number of songs sung before sunrise $\left(r_{9}=0.46, P=0.15\right)$ as well as after sunrise $\left(r_{9}=0.55, P=0.082\right)$, and on number of 
songs sung before sunset $\left(r_{9}=0.50, P=0.11\right)$ as well as after sunset $\left(r_{9}=0.24, P=0.47\right)$.

\section{Dawn singing}

The 11 Wrens started to sing at dawn $32.5 \pm 11.1 \mathrm{~min}$ before sunrise in the morning before playback (second morning; Fig. 1), and $34.1 \pm 10.2 \mathrm{~min}$ before sunrise in the morning after playback (third morning). Thus, the onset of singing did not change significantly after playback (paired $t$ test, $t_{10}=-0.58, P=0.58$ ), and also did not change during two mornings of control without playback (first morning: $31.5 \pm 8.9 \mathrm{~min}$ before sunrise, second morning: $32.5 \pm 11.1 \mathrm{~min}$ before sunrise; paired $t$ test, $\left.t_{10}=-0.31, P=0.77\right)$. The first Wren started to sing $50 \mathrm{~min}$ before sunrise. To test whether singing before and after sunrise was influenced differentially by playback, we analysed the song output for all subjects during $50 \mathrm{~min}$ before and $50 \mathrm{~min}$ after sunrise separately. As predicted, the song output before sunrise was influenced by the previous day's simulated territorial intrusions. In the morning after the playback, the Wrens sang more songs before sunrise than on the previous day, before playback (Fig. 2, second and third morning; paired $t$ test, $t_{10}=-2.66$, $P=0.024)$. We also censused song output before sunrise during two mornings without playback as a control, and found no significant change in song output (Fig. 2, first and second morning; paired $t$ test, $t_{10}=0.34, P=0.74$ ).

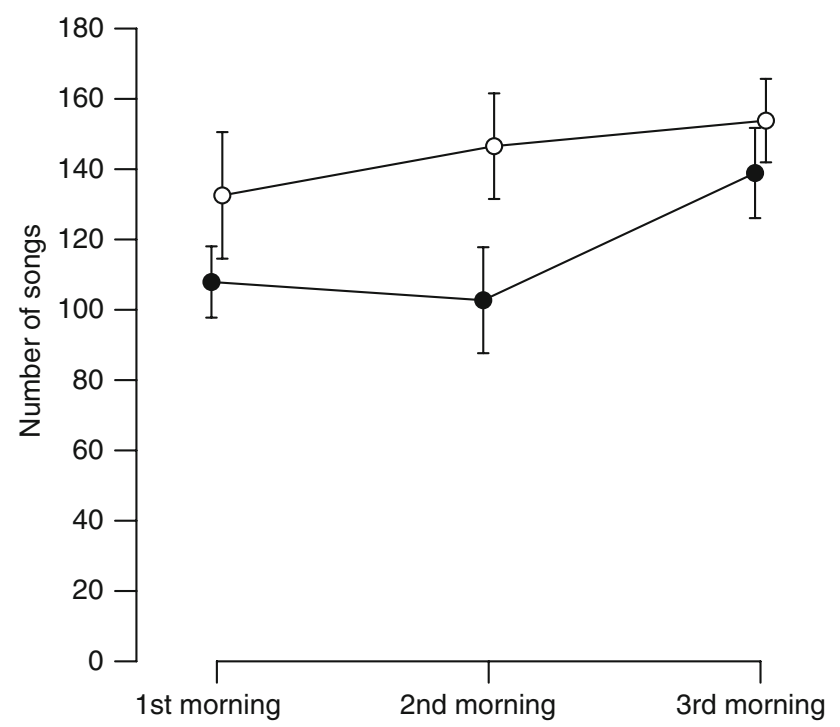

Fig. 2 Mean $( \pm \mathrm{SE})$ number of songs sung by 11 male Winter Wrens before sunrise (closed circle) and during 50 min after sunrise (open circle), on the first morning (control morning), and shortly before (second morning) and 1 day after (third morning) an intrusion was simulated in a male's territory
The song output during the 50 min after sunrise was less clearly influenced by playback, and we found no significant difference in the number of songs sung before playback and on the day after playback (Fig. 2; paired $t$ test, $t_{10}=$ $-0.48, P=0.65)$. We also found no significant change in song output after sunrise during two mornings of control without playback (Fig. 2; paired $t$ test, $t_{10}=-0.94$, $P=0.37)$.

\section{Dusk singing}

The last Wrens stopped singing 25 min after sunset. To test whether singing before and after sunset was influenced differentially by playback, we analysed the song output for all subjects during $25 \mathrm{~min}$ before and $25 \mathrm{~min}$ after sunset separately.

After sunset, only part of the Wrens were singing. Before playback, there were four males and three males singing during the first and during the second evening, respectively, and in the evening after the playback there were six males singing. The song output after sunset seemed to be slightly influenced by the territorial intrusions that were simulated in the morning. In the evening before the territorial challenge, the 11 subjects sang $2 \pm 4$ songs in the $25 \mathrm{~min}$ after sunset, while in the evening after the territorial challenge, they sang $6 \pm 9$ songs after sunset (Wilcoxon signed rank test, $V=1.5, n=11, P=0.042$ ). From the first to the second evening, without playback (the control period), we found no significant change in song output (Wilcoxon signed rank test, $V=14, n=11$, $P=0.11)$.

Also before sunset, only some of the Wrens were singing. During the two evenings before playback, there were seven males singing during the first and eight males during the second evening, respectively, and in the evening after the playback there were seven males singing. The song output during the $25 \mathrm{~min}$ before sunset was not found to be influenced by playback. While on the evening before playback, the 11 Wrens sang $6 \pm 7$ songs during the 25 min before sunset, they sang $10 \pm 17$ songs during the 25 min before sunset on the evening after the playback (Wilcoxon signed rank test, $V=24.5, n=11, P=0.79$ ). From the first to the second evening, without playback (the control period), we also found no significant change in song output (Wilcoxon signed rank test, $V=40, n=11$, $P=0.22)$.

\section{Comparison between seasons}

In the previous autumn study, the first males started to sing at dawn $32 \mathrm{~min}$ before sunrise, and the average starting 
time was $23.0 \pm 8.9 \mathrm{~min}$ before sunrise (Amrhein and Erne 2006). This was significantly later than the average starting time in spring $(32.5 \pm 11.1 \mathrm{~min}$ before sunrise; Welch two sample $t$ test, $t_{18.8}=2.16, P=0.044$ ). To compare dawn song output in spring and autumn, we pooled the data from the two experiments. In a first linear mixed effects model on square root transformed number of songs, we considered song output only during the $32 \mathrm{~min}$ before sunrise for both the spring and the autumn study period (in order to compare the same periods of time before sunrise in both seasons). We found that males sang more songs during the $32 \mathrm{~min}$ before sunrise in spring than in autumn $\left(F_{1,19}=21.02, P<0.001\right)$. Males also sang more songs in the morning after the playback than before playback $\left(F_{1,20}=4.69, P=0.043\right)$, but we found no evidence that the increase in singing activity after playback was different in spring and in autumn (interaction: $F_{1,19}=1.37, P=0.26$ ).

In a second linear mixed effects model, we compared the square root transformed numbers of songs sung during the full time periods of dawn singing before sunrise in spring (during $50 \mathrm{~min}$ before sunrise) and autumn (during $32 \mathrm{~min}$ before sunrise). Again, the higher song output in spring than in autumn $\left(F_{1,19}=26.87\right.$, $P<0.001)$ and the increase of dawn song output 1 day after playback $\left(F_{1,20}=7.07, P=0.015\right)$ were both significant. However, the interaction was not significant $\left(F_{1,19}=2.57, \quad P=0.12\right)$, indicating that while the increase in absolute numbers of songs sung in the morning after playback seemed to be greater in spring than in autumn, the proportional increase relative to the overall song output was similar in both seasons (Fig. 3). The latter result was confirmed using a third linear mixed effects model in which we divided the untransformed full number of songs sung before sunrise in spring and autumn by the respective mean number of songs per season, so that the model was corrected for the difference in overall song output between spring and autumn $\left(F_{1,19}=0, P=1\right)$. Again, the increase of dawn song output 1 day after playback was significant $\left(F_{1,20}=11.68, P=0.003\right)$, but the interaction was not $\left(F_{1,19}=1.86, P=0.19\right)$.

Song immediately after playback

During the $30 \mathrm{~min}$ immediately after each of the two playbacks, male Wrens sang many more songs in spring than in autumn (Fig. 4; linear mixed effects model on square root transformed number of songs: $F_{1,19}=13.20$, $P=0.002$ ). The moderate increase in the $30 \mathrm{~min}$ after the second playback as compared to the $30 \mathrm{~min}$ after the first playback was not significant $\left(F_{1,20}=1.28, P=0.27\right)$, nor

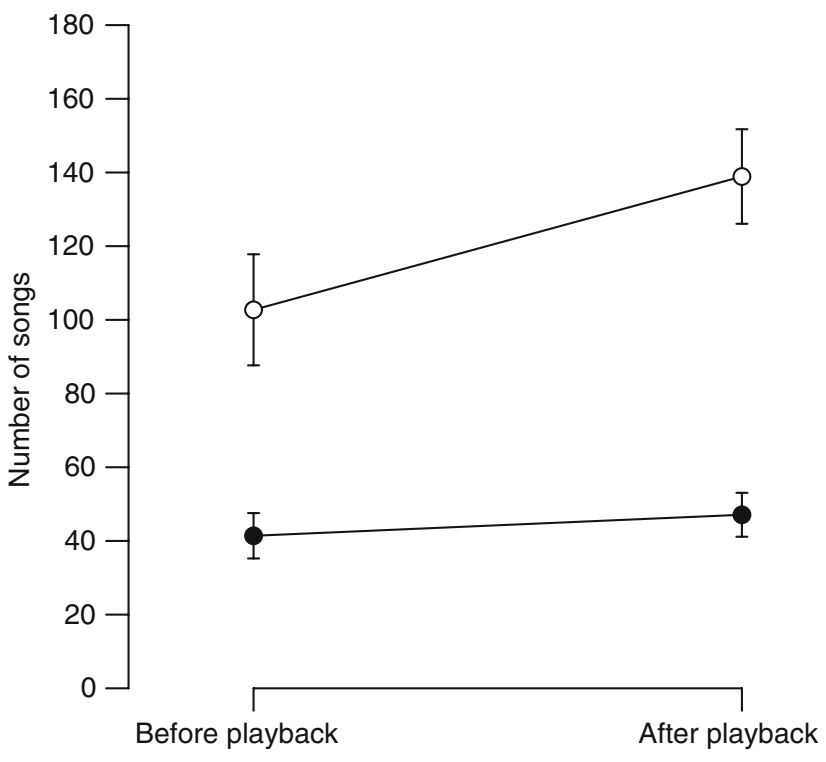

Fig. 3 Mean ( \pm SE) number of songs sung before sunrise by 10 male Winter Wrens in autumn (closed circle) and by 11 males in spring (open circle), shortly before and 1 day after an intrusion was simulated in a male's territory. Note that the time periods spent singing before sunrise differed between seasons, because the Wrens started singing earlier relative to sunrise in spring than in autumn (see text)

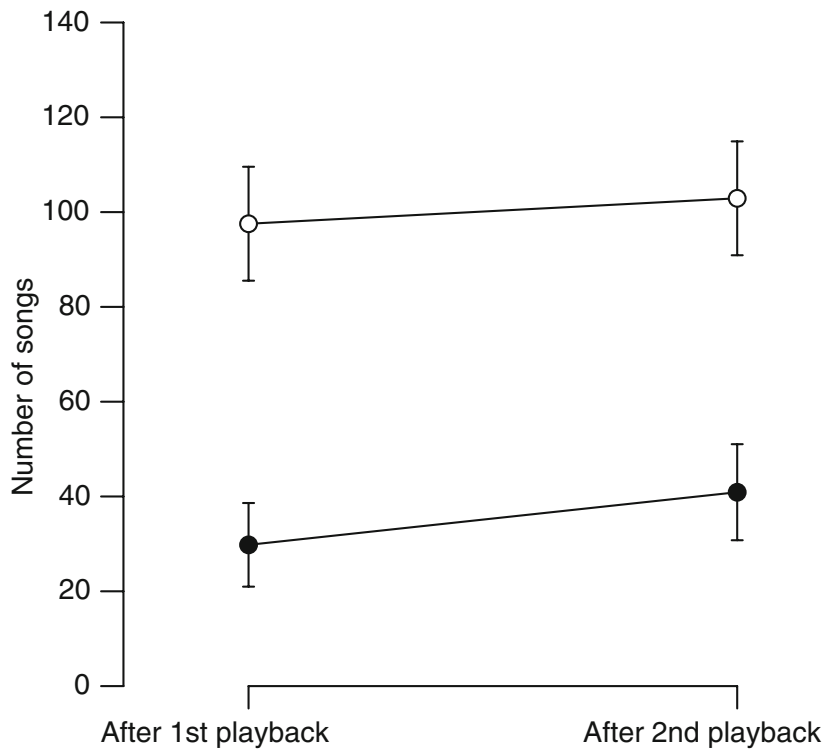

Fig. 4 Mean $( \pm$ SE) number of songs sung during 30 min by 10 male Winter Wrens in autumn (closed circle) and by 11 males in spring (open circle). In each season, two playbacks of 3 min duration were performed, each followed by 30-min periods in which the number of songs were counted. The second playback was started $30 \mathrm{~min}$ after the end of the first playback

was there a significant interaction between season and response to first or second playback $\left(F_{1,19}=1.19\right.$, $P=0.29)$. 


\section{Discussion}

Male Winter Wrens in spring territories significantly increased dawn song output before sunrise 1 day after we simulated an intrusion of a rival into their territory. Also at dusk, after sunset, the Wrens slightly increased song output after the playback. After sunrise and before sunset, however, males were not found to alter their song output following the territorial challenge. Between 2 days of control without song playback, we also found no significant changes of song output.

These results suggest that male Wrens adjusted dawn singing behaviour in response to past territorial challenges and thus confirm our previous findings on autumnal singing behaviour (Amrhein and Erne 2006). Related findings about long-term effects of song playback on behaviour during diurnal singing interactions were obtained in studies on the Banded Wren (Thryothorus pleurostictus; Hall et al. 2006) and on the Nightingale (Luscinia megarhynchos; Schmidt et al. 2007). In the Winter Wren, singing before sunrise may have an important function in spring as well as in autumn, since in both seasons, male Wrens increased song output before sunrise, but not after sunrise. Singing after sunrise could also be less influenced by territorial intrusions because territory defence strategies other than singing become more important as light levels are increasing (Amrhein and Erne 2006). In any case, because we made the playback $1 \mathrm{~h}$ after sunrise, the increase in singing before sunrise cannot be explained only by an unspecific long-term reaction that is timed to the hour of the intrusion.

Winter Wrens sang much more songs at dawn in spring than in autumn, and also directly after the playbacks they sang more songs in spring than in autumn. This is in line with a study on male Carolina Wrens Thryothorus ludovicianus, which sing more songs and are more likely to attack an intruder during the breeding season than in autumn (Hyman 2005). In both seasons, we found a second singing male in one of the territories of our subjects. This suggests that in autumn as well as during the breeding season, territorial intrusions by other males do naturally occur and are likely to be a real threat to the residents. However, while we suggest the predominant function of autumnal dawn singing to be territory defence in the Winter Wren (Amrhein and Erne 2006), additional functions of singing during the breeding season are likely to be guarding or attracting mates (Garson 1980; Mace 1987; Welling et al. 1995; Hyman 2005). In spring, increased singing at dawn on the day after a territorial challenge could therefore also serve to repel rival males to defend fertile females (Tobias and Seddon 2000). Alternatively, increased singing activity after a territorial challenge in spring could function in strengthening the pair bond, because territorial intrusions might lead to females pursuing extra-pair copulations (Mennill et al. 2002). Furthermore, breeding and feeding of young takes place within a male Wren's territory (Garson 1980), so a spring territory probably also serves to secure resources for the raising of the young (Armstrong 1956). For those reasons, a territory is likely to be more valuable and to be defended more vigorously in spring than in autumn. Interestingly, though, the proportional increase of singing activity on the day after playback was similar in spring and in autumn, although the increase in the absolute number of songs seemed to be greater in spring. One might argue, therefore, that beyond the generally higher level of singing activity in spring, the relative strength of long-term response to a simulated territorial intrusion was not greater during the breeding season than in autumn. This finding may indicate that a further increase of signalling effort beyond a particular baseline level may be costly and may thus be held constant relative to the baseline levels of the respective seasons.

Similar to singing before sunrise, singing after sunset may serve to repel rival males or to strengthen the pair bond, since also at that time of the day, some Wrens slightly increased song output after a territorial intrusion was simulated in the morning. However, male Wrens generally sang very little around sunset, and several subjects did not sing at all, so that we doubt the effect we found is of much biological importance. Also Armstrong (1955) observed only a minor peak of song at dusk in the Winter Wren, with some birds singing only a few songs. So far, few studies have investigated the functions of the dusk chorus in songbirds. It was argued that if, before sunset, a bird has gathered enough energy reserves to survive the night, it may recommence singing at dusk (Hutchinson et al. 1993; Hutchinson 2002). According to Kacelnik (1979), the dusk peak of song may be smaller than the dawn peak because of the direction of the change in light intensity. Early in the morning, the light levels and thus the profitability of foraging are increasing, so a bird can first sing and then has plenty of time to forage afterwards. At dusk, birds have to gather enough food to survive the night even if foraging profitability is low at low light levels, because after nightfall, foraging must be abandoned. Thus, many birds probably have less time to spend singing at dusk than at dawn (Kacelnik 1979). Because Winter Wrens showed rather low singing activity after sunset, it seems questionable whether dusk singing plays a role as important as dawn singing. However, if singing is more costly at dusk than at dawn in terms of time lost for feeding, then singing at dusk in response to a territorial intrusion might still honestly reflect a male's quality.

For Winter Wrens singing in an autumn territory or during the breeding season, respectively, the social 
contexts may differ widely, which seems to be reflected in the seasonally different intensities of singing. Future studies could investigate how song parameters such as song length or song repertoire change in the long-term after a territorial challenge. However, based on the results on the number of songs, it appears that simulated territorial intrusions have long-term effects on singing of Winter Wrens before sunrise both in autumn and spring.

\section{Zusammenfassung}

Langzeit-Einfluss von Gesangs-Playback auf den

Gesang des Zaunkönigs in der Morgen- und

Abenddämmerung: Vergleich Frühjahr gegen Herbst

Die Männchen vieler Singvogelarten singen am meisten während der Morgen- und Abenddämmerung. Der Gesang während dieser Dämmerstunden kann zur Revierverteidigung dienen, und es wird angenommen, dass die Männchen ihre Gesangsaktivität an die Häufigkeit anpassen, mit der andere Männchen in ihr Revier eindringen. In dieser Studie benutzten wir Gesangs-Playback, um während der Brutzeit kurz nach Sonnenaufgang Eindringlinge in die Reviere von männlichen Zaunkönigen (Troglodytes troglodytes) zu simulieren. Wir verglichen das Gesangsverhalten der Männchen während der Morgen- und Abenddämmerung kurz vor, und ein Tag nach dem Playback. Ein Tag nach dem Playback sangen die Zaunkönige mehr Strophen vor Sonnenaufgang, was unsere Ergebnisse aus einer früheren Studie über den Morgengesang in Herbst-Revieren bestätigt. Am Abend, der auf das Playback folgte, sangen die Männchen nach Sonnenuntergang ein paar Strophen mehr als vor dem Playback. Die Gesangsaktivität in der Abenddämmerung war aber generell sehr gering. Wir fanden keine signifikanten Änderungen in der Gesangsaktivität nach Sonnenaufgang, vor Sonnenuntergang, und zwischen zwei Tagen ohne Playback, die als Kontrolle dienten. Unsere Ergebnisse sind vereinbar mit der Hypothese, dass Gesang während der Morgen- und Abenddämmerung im Frühjahr eine wichtige Rolle bei der Revierverteidigung spielt. Anders als im Herbst kann eine erhöhte Gesangsaktivität in der Morgen- und Abenddämmerung im Frühjahr aber auch dazu dienen, fruchtbare Weibchen zu verteidigen oder nach einer territorialen Auseinandersetzung den Paarbund zu festigen. Im Vergleich mit den Ergebnissen aus der Herbststudie fingen männliche Zaunkönige während der Brutzeit vor Sonnenaufgang früher an zu singen, und sie sangen generell mehr Strophen vor Sonnenaufgang und direkt nach dem Playback. Der Anstieg in der Gesangsaktivität am Morgen nach dem Playback war in absoluten Strophenzahlen offenbar im Frühjahr größer als im Herbst; jedoch war der proportionale Anstieg, auf die jeweilige allgemeine Gesangsaktivität bezogen, in beiden Jahreszeiten ähnlich.

Acknowledgments For helpful comments and discussions, we thank David Basler, Fleur Daugey, Dieter Ebert, Heinrich Erne, Pius Korner, Fraenzi Korner-Nievergelt, Hansjoerg Kunc, Martin Lutsch, Marc Naguib and Rouven Schmidt. The research was funded by the Swiss Association Pro Petite Camargue Alsacienne and the Freiwillige Akademische Gesellschaft Basel. Our experiments comply with the current laws of France.

\section{References}

Amrhein V, Erne N (2006) Dawn singing reflects past territorial challenges in the winter wren. Anim Behav 71:1075-1080

Amrhein V, Kunc HP, Naguib M (2004) Non-territorial nightingales prospect territories during the dawn chorus. Proc R Soc Lond B (Suppl) 271:S167-S169

Armstrong EA (1955) The wren. Collins, London

Armstrong EA (1956) Territory in the wren Troglodytes troglodytes. Ibis 98:430-437

Armstrong EA (1977) Behavioural adaptions of the wren. Biol Rev $52: 235-294$

Cramp S (ed) (1988) The birds of the western palearctic, vol 5. Oxford University Press, Oxford

Cuthill IC, Macdonald WA (1990) Experimental manipulation of the dawn and dusk chorus in the blackbird Turdus merula. Behav Ecol Sociobiol 26:209-216

Dallmann M (1987) Der Zaunkönig, Troglodytes troglodytes. Neue Brehm-Bücherei, Bd. 577. Westarp Wissenschaften, Magdeburg

Davies NB, Houston AI (1984) Territory economics. In: Krebs JR, Davies NB (eds) Behavioural ecology: an evolutionary approach, 2nd edn. Blackwell, Oxford, pp 148-169

Double M, Cockburn A (2000) Pre-dawn infidelity: females control extra-pair mating in superb fairy-wrens. Proc R Soc Lond B 267:465-470

Garson PJ (1980) Male behaviour and female choice: mate selection in the wren? Anim Behav 28:491-502

Glutz von Blotzheim UN (ed) (1985) Handbuch der Vögel Mitteleuropas, Band 10/2. AULA, Wiesbaden

Hall ML, Illes A, Vehrencamp SL (2006) Overlapping signals in banded wrens: long-term effects of prior experience on males and females. Behav Ecol 17:260-269

Hutchinson JMC (2002) Two explanations of the dawn chorus compared: how monotonically changing light levels favour a short break from singing. Anim Behav 64:527-539

Hutchinson JMC, McNamara JM, Cuthill IC (1993) Song, sexual selection, starvation and strategic handicaps. Anim Behav 45:1153-1177

Hyman J (2005) Seasonal variation in response to neighbors and strangers by a territorial songbird. Ethology 111:951-961

Kacelnik A (1979) The foraging efficiency of great tits (Parus major) in relation to light intensity. Anim Behav 27:237-241

Kacelnik A, Krebs JR (1983) The dawn chorus in the great tit (Parus major): proximate and ultimate causes. Behaviour 83:287-309

Kunc HP, Amrhein V, Naguib M (2005) Seasonal variation in dawn song characteristics in the common nightingale. Anim Behav 70:1265-1271

Liu W-C (2004) The effect of neighbours and females on dawn and daytime singing behaviours by male chipping sparrows. Anim Behav 68:39-44

Mace R (1987) The dawn chorus in the great tit Parus major is directly related to female fertility. Nature 330:745-746 
McDonald MV (1989) Function of song in Scott's seaside sparrow, Ammodramus maritimus peninsulae. Anim Behav 38:468-485

McNamara JM, Mace RH, Houston AI (1987) Optimal daily routines of singing and foraging in a bird singing to attract a mate. Behav Ecol Sociobiol 20:399-405

Mennill DJ, Ratcliffe LM, Boag PT (2002) Female eavesdropping on male song contests in songbirds. Science 296:873

Naguib M, Amrhein V, Kunc HP (2004) Effects of territorial intrusions on eavesdropping neighbors: communication networks in nightingales. Behav Ecol 15:1011-1015

R Development Core Team (2006) R: a language and environment for statistical computing. R Foundation for Statistical Computing, Vienna. http://www.R-project.org

Schmidt R, Amrhein V, Kunc HP, Naguib M (2007) The day after: effects of vocal interactions on territory defence in nightingales. J Anim Ecol 76:168-173

Slagsvold T, Dale S, Sætre G-P (1994) Dawn singing in the great tit (Parus major): mate attraction, mate guarding, or territorial defence? Behaviour 131:115-138
Staicer CA, Spector DA, Horn AG (1996) The dawn chorus and other diel patterns in acoustic signaling. In: Kroodsma DE, Miller EH (eds) Ecology and evolution of acoustic communication in birds. Cornell University Press, Ithaca, pp 426-453

Stamps JA, Krishnan VV (2001) How territorial animals compete for divisible space: a learning-based model with unequal competitors. Am Nat 157:154-169

Switzer PV, Stamps JA, Mangel M (2001) When should a territory resident attack? Anim Behav 62:749-759

Tobias J, Seddon N (2000) Territoriality as a paternity guard in the European robin, Erithacus rubecula. Anim Behav 60:165-173

Trillo PA, Vehrencamp SL (2005) Song types and their structural features are associated with specific contexts in the banded wren. Anim Behav 70:921-935

Welling P, Koivula K, Lahti K (1995) The dawn chorus is linked with female fertility in the Willow tit Parus montanus. J Avian Biol 26:241-246 